\title{
Classes Interativas: uma proposta pedagógica
}

Recebido em 29.04.2015. Aprovado em 05.05. 2015 Avaliado pelo sistema double blind review

\author{
Marcio Augusto Silva de Araújo \\ iegrs_caxias@yahoo.com.br \\ I. E. Governador Roberto Silveira - Duque de Caxias - RJ - Brasil.
}

\section{Resumo}

Em 2011 o atual Secretário de Educação Wilson Risolia assume a Secretaria de Educação do Estado do Rio de Janeiro e inicia o processo de reestruturação do ensino. Dentre as principais medidas: elevar os índices nacionais da educação pública estadual que na época encontrava-se em $26^{\circ}$ lugar. Hoje depois de se passarem três ( 3) anos na Gestão como Secretário, o Rio de Janeiro encontra-se em $3^{\circ}$ lugar.

A partir da utilização dos resultados obtidos no IDEB e a implementação das avaliações externas, conseguese aplicar ações efetivas com intuito de melhorar o desempenho dos alunos, como diagnosticar as disciplinas críticas que apresentam maior número de alunos com dificuldade e suas causas. Ao mesmo tempo em que desenvolve essas ações, possibilitou aos gestores das Unidades Escolares um curso de pós graduação (MBA), que torna efetivamente até então um professor regente em um Gestor, para atender as reais demandas de cada escola.

Verificamos nas últimas avaliações externas, que nas disciplinas críticas não conseguimos diminuir e reverter os resultados negativos do processo ensino-aprendizagem dos alunos em nossa Unidade Escolar.

O crescente e irreversível avanço da tecnologia em todos os campos da vida do ser humano demanda uma constante reciclagem nos métodos de ensino-aprendizagem oferecidos pelas instituições de ensino. 0 Instituto de Educação Governador Roberto Silveira almeja, através deste projeto piloto nas escolas públicas de formação de professores, acompanhar esses avanços que envolvem a vida do aluno.

A parceria com uma grande empresa renomada no setor de tecnologia (Hitachi), que além da doação de 21 equipamentos (Lousa Digital), no valor total de $\mathrm{R} \$ 76.650,00$ fornecerá suporte pedagógico propiciando que este projeto possa ser desenvolvido na prática.

Temos o intuito de elevar o desempenho e melhorar os resultados das disciplinas críticas elencadas neste projeto, além de diminuir a evasão escolar com aulas mais atrativas e significativas, com isto apresentamos este projeto com o custo de investimento no valor de $\mathrm{R} \$ 89.885,25$.

Palavras-chaves: Educação. Tecnologias educacionais. Plano de empreendimento. Classes interativas. 


\section{Contexto da escola}

A escola I. E. GOVERNADOR ROBERTO SILVEIRA foi fundada em 1962 em Duque de Caxias, no Rio de Janeiro. São 1342 alunos atendidos nas séries: Educação Especial, Ensino Fundamental ( $2^{\circ}$ segmento), Programa Autonomia, Curso Normal e Ensino Médio

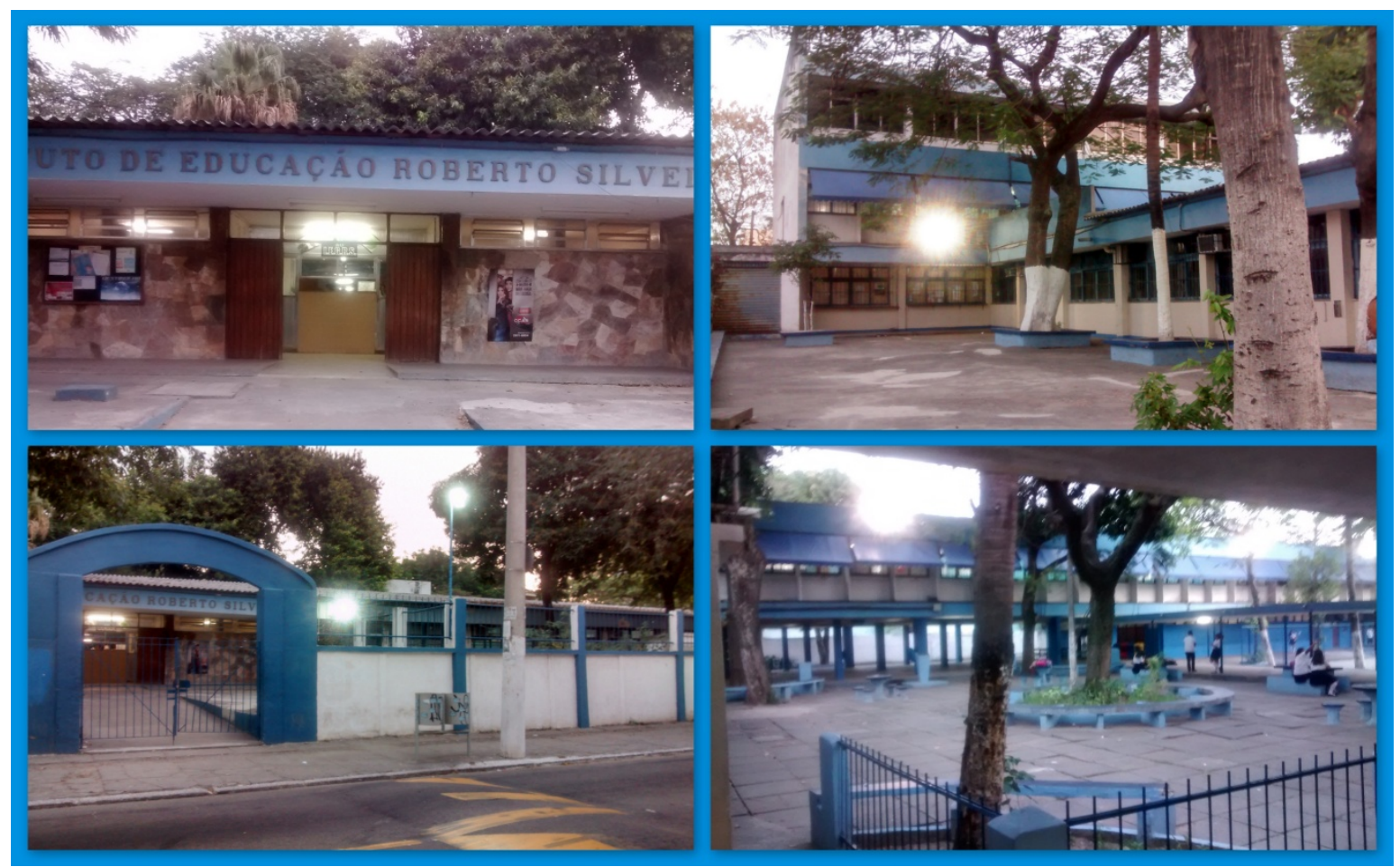

\section{Missão:}

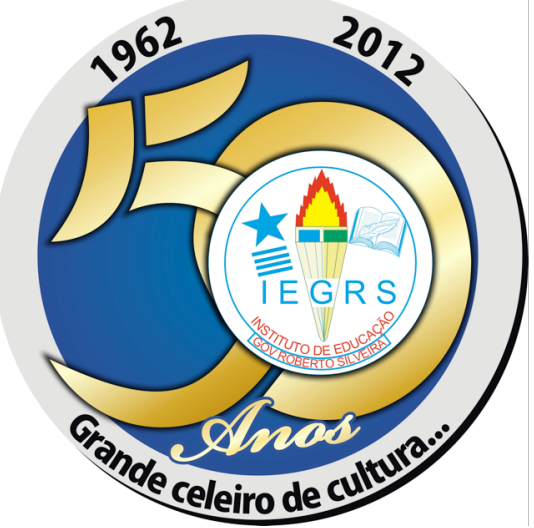

Formar cidadãos participativos e questionadores, preparando-os para o mundo do trabalho e desenvolvimento humano garantindo uma aprendizagem efetiva, considerando sua inserção numa sociedade globalizada, competitiva e inclusiva.

\section{Visão:}

Ser reconhecida pela capacidade de formar professores que buscam a qualidade do ensino, o crescimento e 0 desenvolvimento integral dos alunos buscando contribuir na formação de habilidades e competências necessárias para alcançarmos uma sociedade igualitária. 


\section{Instalações}

O I.E.Governador Roberto Silveira é uma escola de grande porte que possui 28 salas de aula, 01 sala de direção geral, 01 sala de direção adjunta, 01 secretaria, 01 sala de Departamento Pessoal, 01 sala de coordenação pedagógica, 01 sala de orientação educacional, 02 salas de coordenação de turno, 01 sala de práticas pedagógicas,02 salas de vídeo, 02 salas interligadas de laboratório de informática, 01 laboratório de ciências físicas e biológicas, 01 biblioteca, 01 auditório, 01 refeitório, 01 cozinha, 01 sala de educação física, 01 sala de artes, 01 sala multifuncional,01 almoxarifado, 01 sala de mecanografia, 01 Instituto Histórico do IEGRS, 01 arquivo morto, 01 vestiário de funcionários, 02 sala de Projetos(Oficinas do Programa da SEEDUC: Escola em Movimento- 01cultural e 01 guarda de material esportivo), 02 salas em parceria com o CEPEMHed (Centro de Pesquisa e Memória da Educação do município de Duque de Caxias),onde é feita a pesquisa documental e higienização do acervo do Instituto Histórico do IEGRS e outras instituições de ensino do município, 02 quadras poliesportivas,sendo uma coberta e uma descoberta, 01 pátio coberto e 01 descoberto, 01 área externa situada a frente da escola, 01 estacionamento, 01 prédio anexo onde funcionou a Educação Infantil e ainda abriga o antigo refeitório, 01 sala guarda livros, 01 área coberta para execução de trabalhos diversos, 06 banheiros de alunos, 03 masculino/03 feminino, com acessibilidade, incluindo vestiários, 02 banheiros para professores $(01 \mathrm{M} / 01 \mathrm{~F})$, todos no térreo, 02 banheiros de alunos $(01 \mathrm{M} / 01 \mathrm{~F})$, e 01 banheiro para professores(01M/01F), no $2^{\circ}$ pavimento, $01 \mathrm{NTE}$ (Núcleo de Tecnologia Educacional, com 02 salas base e 02 laboratórios de informática educativa).

Mesmo sendo uma Instituição de Ensino que se destaca em nosso município, é importante ressaltar que o prédio é muito antigo e a estrutura da rede física e elétrica está muito comprometida. O recurso destinado a manutenção mensal é insuficiente, pois os gastos com material para pequenas obras e reparos são constantes. Dentre tantos problemas, pontuamos alguns que consideramos mais graves e emergentes: telhados do $2^{\circ}$ pavimento (grande quantidade de goteiras); distribuição adequada da rede elétrica, incluindo novos quadros de distribuição (risco de curto-circuito), reforma das quadras esportivas com reforma e ampliação dos vestiários, substituição dos tacos das salas de aula (úmidos, soltos, com cupins), por pisos, conserto da passarela de ligação dos dois prédios, reboco externo do auditório caindo ( $3^{\circ}$ pavimento), juntas de dilatação cedendo, sistema de drenagem do pátio e quadras incluindo nova pavimentação dos mesmos, pintura geral dos prédios, reforma do Auditório de grande porte (capacidade para 300 pessoas): bancos, teto, telhados.

O quadro a seguir apresenta a relação dos acontecimentos mais relevantes para a evolução da escola, desde a fundação até hoje.

\begin{tabular}{|l|l|}
\hline Ano & Acontecimentos relevantes \\
\hline 1962 & $\begin{array}{l}\text { Foi fundado em 12 de junho - }{ }^{0} \text { Diretor: Álvaro Lopes } \\
\text { Criação do Grupo Escolar, do Jardim de Infância, do Ginásio, do Curso Normal } \\
\text { (Decreto n 12.875, de 28/01/1967) }\end{array}$ \\
\hline 1964 & $\begin{array}{l}\text { Implementação de setores diversos: Biblioteca Pedro II, Laboratório (Instituto de } \\
\text { Pesquisas Físicas e Biológicas) e Salas de Pedagogia Experimental. }\end{array}$ \\
\hline 1964 A 1968 & Funciona como Centro de Treinamento de Professores Leigos \\
\hline 1967 & Criação da Faculdade de Educação da Baixada(FEBEF) \\
\hline 1969 & $\begin{array}{l}\text { Reconhecimento do Curso Superior de Pedagogia da Faculdade de Educação do } \\
\text { I.E.Gov. Roberto Silveira }\end{array}$ \\
\hline
\end{tabular}




\begin{tabular}{|c|c|}
\hline $\begin{array}{l}1973 / 1980 \\
1994 / 1999\end{array}$ & Implantação, no turno da noite do Curso de Estudos Adicionais \\
\hline $\begin{array}{l}1975 \\
\text { A } \\
2000\end{array}$ & $\begin{array}{l}\text { Institui oferta de cursos profissionalizantes em diversas áreas: Administração, } \\
\text { Publicidade, Secretariado, Técnico em Contabilidade e Técnico em Crédito e } \\
\text { Finanças }\end{array}$ \\
\hline 1982 & Assume a direção do IEGRS o primeiro Diretor Geral eleito pela comunidade \\
\hline 1986 & $\begin{array}{l}\text { Extintos cursos profissionalizantes, criação Curso de Formação Geral, que muda a } \\
\text { nomenclatura em } 1996 \text { ( } 2^{\circ} \mathrm{Grau} \text { ) e em } 2000 \text { (Ensino Médio) }\end{array}$ \\
\hline $\begin{array}{l}1988 \\
\text { A } \\
1998\end{array}$ & Implementação e funcionamento do Curso Normal no noturno \\
\hline 1992 & Construção da quadra poliesportiva coberta \\
\hline 1997 & Transferência da FEBEF para prédio próprio \\
\hline 1999 & Pela primeira vez, uma mulher, assume a direção geral do IEGRS \\
\hline 1999 & $\begin{array}{l}\text { Reforma Transitória do Ensino Médio, ampliação do Ensino Médio noturno e } \\
\text { implantação o Ensino Fundamental regular, no noturno, para alunos com série/idade } \\
\text { destorcida. }\end{array}$ \\
\hline 2002 & Implantação das Salas de Recursos \\
\hline 2002 & Mudança na grade curricular cria o Curso Normal em 04 anos \\
\hline 2006 & Criação do Instituto Histórico do IEGRS \\
\hline 2009 & $\begin{array}{l}\text { Instituído em parceria com a Fundação Roberto Marinho o Programa Autonomia } \\
\text { para o Ensino Médio Formação Geral visando aceleração da aprendizagem dos } \\
\text { jovens com distorção idade/série }\end{array}$ \\
\hline 2008 & Extinção da Educação Infantil \\
\hline 2008 & $\begin{array}{l}\text { É criado o projeto interdisciplinar denominado "Mostra de Dança" que trabalha temas } \\
\text { transversais utilizando diversas formas de expressão da cultura popular e que será } \\
\text { realizado anualmente }\end{array}$ \\
\hline $\begin{array}{l}2009 \\
\text { A } \\
2011\end{array}$ & $\begin{array}{l}\text { Realização do Curso Normal semipresencial, PRO-INFANTIL criado pelo MEC em } \\
\text { parceria com a Prefeitura para habilitar estimuladoras no exercício do magistério, } \\
\text { uma parceria no âmbito das três esferas educacionais }\end{array}$ \\
\hline 2009 & $\begin{array}{l}\text { Ampliação das parcerias com as universidades (UERJ,UFRJ,UNIRIO), com a criação } \\
\text { de projetos de pesquisa, com alunos e professores pesquisadores e projetos de } \\
\text { reforço escolar }\end{array}$ \\
\hline 2010 & $\begin{array}{l}\text { Participação da diretora da Instituição como representante de nosso município da } \\
\text { CONAE - Conferência Nacional de Educação aberta pelo Poder Público para } \\
\text { democratização do desenvolvimento da Educação Nacional }\end{array}$ \\
\hline
\end{tabular}




\section{Classes Interativas: uma proposta pedagógica}

\begin{tabular}{|l|l|}
\hline 2010 & Mudança na matriz curricular institui o Curso Normal em 03 anos em horário Integral \\
\hline 2011 & Extinção do $1^{\text {0 }}$ Segmento do Ensino Fundamental \\
\hline 2012 & Término do Curso Normal em 04 anos \\
\hline 2012 & $\begin{array}{l}\text { Participação dos alunos do Curso Normal na Oficina de Vídeo interatividade com o } \\
\text { vídeo "No lixão com a câmera na mão", que vem sendo premiado nacional e } \\
\text { internacionalmente. }\end{array}$ \\
\hline 2013 & $\begin{array}{l}\text { Criação da primeira turma de Classe Especial, com manutenção das salas de } \\
\text { recursos já existentes }\end{array}$ \\
\hline $\begin{array}{l}\text { Instituído em parceria com a Fundação Roberto Marinho o Programa Autonomia } \\
\text { para o 2 } \\
\text { dos jovens com distorção idade série }\end{array}$ \\
\hline
\end{tabular}

\section{Professores e funcionários}

A equipe é formada por 150 professores, distribuídos da seguinte forma:

\section{Regentes:}

\begin{tabular}{|l|l|}
\hline Disciplina / Área & Quant. de professores \\
\hline ARTES & 4 \\
\hline BIOLOGIA & 2 \\
\hline FISICA & 4 \\
\hline QUÍMICA & 4 \\
\hline MATEMÁTICA & 14 \\
\hline FILOSOFIA & 2 \\
\hline SOCIOLOGIA & 6 \\
\hline INGLÊS & 9 \\
\hline ESPANHOL & 2 \\
\hline EDUCAÇÃO FÍSICA & 9 \\
\hline HISTÓRIA & 8 \\
\hline GEOGRAFIA & 8 \\
\hline PRODUÇÃO TEXTUAL & 4 \\
\hline RESOLUÇÃO DE PROBLEMAS & 3 \\
\hline PORTUGUES & 14 \\
\hline CIÊNCIAS & 3 \\
\hline ENSINO RELIGIOSO & 2 \\
\hline PPP & 11 \\
\hline
\end{tabular}




\begin{tabular}{|l|l|}
\hline CDPEI & 2 \\
\hline PPIP (Laboratório Pedagógico) & 1 \\
\hline HISTÓRIA E FILOSOFIA DA EDUCAÇÃO & 4 \\
\hline FUNDAMENTOS PSICOLÓGICOS & 3 \\
\hline ALFA & 4 \\
\hline CDPEF & 1 \\
\hline PEOSE & 1 \\
\hline EJA & 1 \\
\hline
\end{tabular}

\section{Extra Classe:}

\begin{tabular}{|l|l|}
\hline Disciplina / Área & Quant. de professores \\
\hline DIRETOR GERAL / ADJUNTO & $1 / 3=4$ \\
\hline AGENTE DE PESSOAL & 1 \\
\hline SECRETÁRIA & 1 \\
\hline AUXILIAR DE SECRETARIA & 4 \\
\hline COORDENADOR PEDAGÓGICO & 2 \\
\hline COORDENADOR DE TURNO & 5 \\
\hline ORIENTADOR & 2 \\
\hline PROFESSOR ORIENTADOR & 1 \\
\hline PROFESSOR ARTICULADOR PEDAGÓGICO & 1 \\
\hline AGENTE DE LEITURA & 3 \\
\hline
\end{tabular}

Do total de professores efetivos, 03(três) são professores readaptados. Nossos professores atuam na rede pública estadual, municipal e privada de ensino.Todos tem graduação de nível Superior na disciplina em que lecionam; deste total $65 \%$ possui especialização em áreas afins e $8 \%$ possuem mestrado ou estão concluindo.

Além disso, a escola conta com 25 funcionários de apoio terceirizados, sendo distribuídos assim: 11 serventes, 5 porteiros, 9 auxiliares de cozinha.

\section{Perfil dos alunos}

Os alunos estão distribuídos por séries e turnos da seguinte maneira: 


\section{Classes Interativas: uma proposta pedagógica}

\section{Ensino Fundamental, Autonomia e Ensino Médio}

\begin{tabular}{|c|c|c|c|c|c|c|c|c|}
\hline \multirow[b]{2}{*}{ Série/Ano } & \multirow{2}{*}{$\begin{array}{l}\text { Média } \\
\text { de idade }\end{array}$} & \multirow{2}{*}{$\begin{array}{l}\text { Total } \\
\text { de } \\
\text { alunos }\end{array}$} & \multicolumn{2}{|l|}{ Manhã } & \multicolumn{2}{|l|}{ Tarde } & \multicolumn{2}{|l|}{ Noite } \\
\hline & & & $\begin{array}{l}\mathrm{N}^{0} \\
\text { alunos }\end{array}$ & $\begin{array}{l}\mathrm{N}^{0} \\
\text { turmas }\end{array}$ & $\begin{array}{l}\mathrm{N}^{0} \\
\text { alunos }\end{array}$ & $\begin{array}{l}\mathrm{N}^{0} \\
\text { turmas }\end{array}$ & $\begin{array}{l}\mathrm{N}^{\circ} \\
\text { alunos }\end{array}$ & $\begin{array}{l}\mathrm{N}^{\circ} \\
\text { turmas }\end{array}$ \\
\hline $\begin{array}{l}\text { Classe } \\
\text { Especial }\end{array}$ & 20 & 12 & 12 & 1 & & & & \\
\hline $6^{\circ}$ ano & 11 & 35 & 35 & 1 & - & - & - & - \\
\hline $7^{0}$ ano & 12 & 105 & 35 & 3 & - & - & - & - \\
\hline $8^{\circ}$ ano & 13 & 105 & 35 & 3 & - & - & - & - \\
\hline $9^{\circ}$ ano & 14 & 105 & 35 & 3 & - & - & - & - \\
\hline Autonomia & 16 & 30 & 30 & 1 & - & - & - & - \\
\hline $1^{\circ} \mathrm{EM}$. & 16 & 70 & - & - & - & - & 35 & 2 \\
\hline $2^{\circ} \mathrm{EM}$ & 17 & 70 & - & - & - & - & 35 & 2 \\
\hline $3^{\circ} \mathrm{EM}$. & 18 & 70 & - & - & - & - & 35 & 2 \\
\hline TOTAL & - & 602 & - & 12 & - & - & - & 6 \\
\hline
\end{tabular}

\section{Curso Normal Integral}

\begin{tabular}{|l|l|l|l|}
\hline Série/Ano & $\begin{array}{l}\text { Média de } \\
\text { idade }\end{array}$ & $\begin{array}{l}\text { Total de } \\
\text { alunos }\end{array}$ & $\mathrm{N}^{0}$ de turmas \\
\hline $1^{\circ} \mathrm{C} . \mathrm{N}$. & 15 & 210 & 6 \\
\hline $2^{\circ} \mathrm{C} . \mathrm{N}$. & 16 & 315 & 9 \\
\hline $3^{\circ} \mathrm{C} . \mathrm{N}$. & 17 & 210 & 6 \\
\hline TOTAL & - & 735 & 21 \\
\hline
\end{tabular}

Por ser uma escola de tradição em nosso município, um Instituto de Educação com Curso Normal, todos anseiam por uma escola diferenciada, com atividades diversificadas, profissionais qualificados. Muitos buscam realizar o sonho dos pais de ter estudado nela e muitos que atuam são oriundos dela. Daí a maioria dos alunos abraçarem as propostas ofertadas, se empenhando para alcançar índices elevados de excelência. A maioria dos alunos que tem jornada de trabalho é do curso noturno (Ensino Médio), já que o Curso Normal, com sua especificidade de horário integral, não permite tal prática.

As famílias são convidadas a participar ativamente da vida escolar de seus filhos, para que possam acompanhar e auxiliar a escola no caminhar contínuo dos discentes, no tocante ao desempenho escolar e comportamento. Esta parceria permite a redução dos índices de indisciplina e auxilia na conservação do patrimônio escolar.

Devido à localização da escola a comunidade escolar é bastante distinta, onde há alunos que moram próximo, outros mais distantes e ainda em outros municípios. 


\section{Características do entorno}

A escola está inserida na chamada área nobre do município de Duque de Caxias, o Jardim 25 de Agosto. A unidade escolar ocupa um quarteirão e tem como vizinhos o Fórum Municipal de Duque de Caxias e a Vila Olímpica João Gaspar Correa Meyer, onde funciona a Secretaria Municipal de Esporte e Lazer. Há previsão, ainda, de inauguração até o término deste ano de um complexo englobando 03 delegacias civis e o Instituto Médico Legal do município.

O comércio é diversificado: lojas, bancos, hipermercados, universidade privada, que convivem com índices baixos de violência.

Além disso, situa-se próximo ao acesso a Linha Vermelha e devido a proximidade com a Avenida Brigadeiro Lima e Silva, uma das principais avenidas da localidade, o acesso as linha de ônibus municipais e intermunicipais é amplo facilitando o ir e vir do cotidiano.

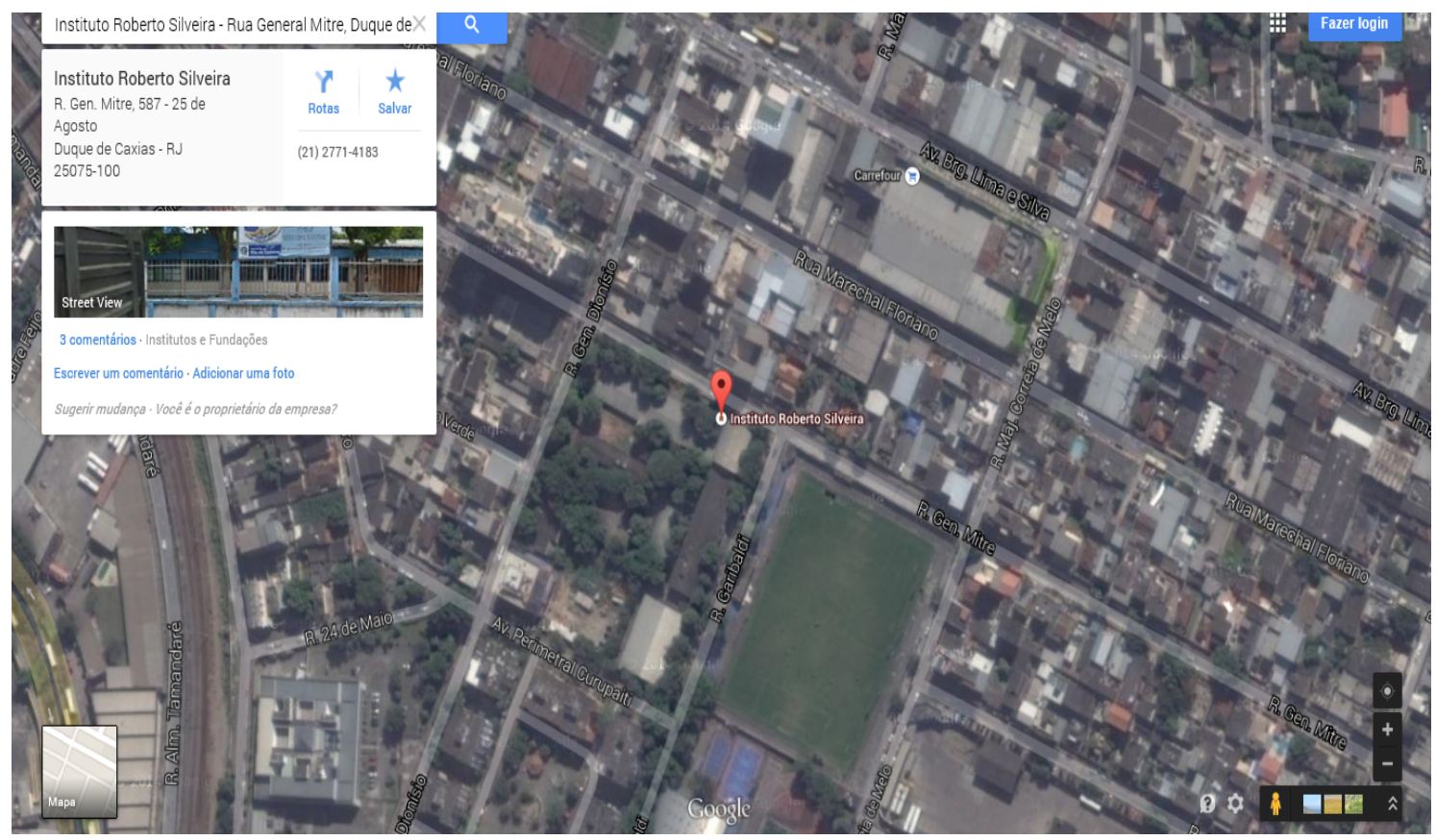

Foto de satélite: Google maps. 


\section{Identificação do problema e da oportunidade}

A identificação do problema partirá de um diagnóstico da Unidade Escolar. Para isso, foram observadas as principais avaliações externas, avaliações da equipe pedagógica, bem como relatórios internos de desempenho.

\section{IDEB}

Resultado IDEB para $8^{\mathrm{a}}$ série $/ 9^{\circ}$ ano ENSINO FUNDAMENTAL

\begin{tabular}{|l|l|l|l|l|l|l|l|l|l|}
\hline ANO & $\mathbf{2 0 0 5}$ & $\mathbf{2 0 0 7}$ & $\mathbf{2 0 0 9}$ & $\mathbf{2 0 1 1}$ & $\mathbf{2 0 1 3}$ & $\mathbf{2 0 1 5}$ & $\mathbf{2 0 1 7}$ & $\mathbf{2 0 1 9}$ & $\mathbf{2 0 2 1}$ \\
\hline Metas projetadas & - & 3,5 & 3,5 & 3,7 & 4,0 & 4,4 & 4,6 & 4,9 & 5,1 \\
\hline Ideb observado & 3,4 & 3,4 & 4,3 & $\mathbf{3 , 6}$ & 4,0 & - & - & - & - \\
\hline
\end{tabular}

Fonte: INEP

Obs.: * Número de participantes na Prova Brasil insuficiente para que os resultados sejam divulgados.

A escola vem alcançando as metas projetadas e mantendo uma constância no IDEB (Índice de Desenvolvimento da Educação Básica). Evidenciando que as ações desenvolvidas pela escola vem alcançado seus objetivos, tanto no fluxo escolar como nas médias do resultado da Prova Brasil/SAEB.

\section{Avaliação estadual}

\section{Para RJ}

Quadro demonstrativo de desempenho 2013 Língua Portuguesa:

\begin{tabular}{|l|l|l|l|l|l|l|l|l|l|l|}
\hline & PROEFICIÊNCIA & $\begin{array}{l}\text { DESVIO } \\
\text { PADRÃO }\end{array}$ & $\begin{array}{l}\text { PADRÃO } \\
\text { DESEMPENHO }\end{array}$ & BAIXO & INTERMEDIÁRIO & ADEQUADO & AVANÇADO & PREV & AVALIA & $\%$ \\
\hline $\begin{array}{l}9^{\circ} \\
\text { ANO }\end{array}$ & 242,7 & 46,1 & INTERMEDIÁRIO & 17,1 & 61 & 18,1 & 3,8 & 116 & 105 & 90,5 \\
\hline $\begin{array}{l}3^{\circ} \\
\text { EM }\end{array}$ & 273,6 & 42,8 & INTERMEDIÁRIO & 24,5 & 45,9 & 27,6 & 2 & 113 & 98 & 86,7 \\
\hline $\begin{array}{l}3^{\circ} \\
\text { CN }\end{array}$ & 282,6 & 42,6 & INTERMEDIÁRIO & 23,7 & 38,2 & 34,1 & 4 & 179 & 173 & 96,6 \\
\hline
\end{tabular}

Os alunos em língua portuguesa demonstram já terem começado um processo de sistematização e domínio das habilidades consideradas básicas e essenciais ao período de escolarização que se encontram. Daí tornar-se importante o investimento nas práticas pedagógicas (atualmente o Reforço Escolar de Língua Portuguesa) para que possam desenvolver habilidades mais elaboradas.

\section{Quadro demonstrativo de desempenho 2013 Matemática:}

\begin{tabular}{|l|l|l|l|l|l|l|l|l|l|l|}
\hline & PROEFICIÊNCIA & $\begin{array}{l}\text { DESVIO } \\
\text { PADRÃO }\end{array}$ & $\begin{array}{l}\text { PADRÃO } \\
\text { DESEMPENHO }\end{array}$ & BAIXO & INTERMEDIÁRIO & ADEQUADO & AVANÇADO & PREV & AVALIA & $\%$ \\
\hline $\begin{array}{l}9^{\circ} \\
\text { ANO }\end{array}$ & 244,1 & 42 & INTERMEDIÁRIO & 34,3 & 56,2 & 9,5 & 0 & 116 & 105 & 90,5 \\
\hline $\begin{array}{l}3^{\circ} \\
\text { EM }\end{array}$ & 259,5 & 44,2 & BAIXO & 66,3 & 31,6 & 1 & 1 & 113 & 98 & 86,7 \\
\hline $\begin{array}{l}3^{\circ} \\
\text { CN }\end{array}$ & 272,9 & 42,7 & BAIXO & 50,6 & 77,1 & 1,7 & 0,6 & 178 & 172 & 96,6 \\
\hline
\end{tabular}


Já em matemática os alunos do Ensino Médio, diferente do Ensino Fundamental, revelam ter desenvolvido competências e habilidades muito aquém do que seria esperado para o período de escolarização em que se encontram. Por isso, esse grupo necessita de uma intervenção focada de modo a progredirem com sucesso em seu processo de escolarização, o que já vem acontecendo através do Reforço Escolar de Matemática.

\section{Avaliações e relatórios internos}

\begin{tabular}{|c|c|c|c|c|c|c|c|}
\hline Série/Ano & $\begin{array}{l}\text { Matrículas } \\
\text { iniciais }\end{array}$ & Evasão & Transf. & $\begin{array}{l}\text { Matrículas } \\
\text { finais }\end{array}$ & Disciplinas & Aprov. & Reprov. \\
\hline \multirow{8}{*}{$6^{\circ}$ ano } & \multirow{8}{*}{92} & \multirow{8}{*}{0} & \multirow{8}{*}{0} & \multirow{8}{*}{92} & Português & 86 & 6 \\
\hline & & & & & Matemática & 54 & 38 \\
\hline & & & & & História & 80 & 12 \\
\hline & & & & & Geografia & 73 & 19 \\
\hline & & & & & Ciências & 59 & 33 \\
\hline & & & & & L. Estrangeira & 76 & 16 \\
\hline & & & & & Ed. Física & 89 & 3 \\
\hline & & & & & Artes & 89 & 3 \\
\hline Série/Ano & $\begin{array}{l}\text { Matrículas } \\
\text { iniciais }\end{array}$ & Evasão & Transf. & $\begin{array}{l}\text { Matrículas } \\
\text { finais }\end{array}$ & Disciplinas & Aprov. & Reprov. \\
\hline \multirow{8}{*}{$7^{\circ}$ ano } & \multirow{8}{*}{101} & \multirow{8}{*}{1} & \multirow{8}{*}{3} & \multirow{8}{*}{97} & Português & 91 & 6 \\
\hline & & & & & Matemática & 94 & 3 \\
\hline & & & & & História & 96 & 1 \\
\hline & & & & & Geografia & 86 & 11 \\
\hline & & & & & Ciências & 92 & 5 \\
\hline & & & & & L. Estrangeira & 97 & 0 \\
\hline & & & & & Ed. Física & 92 & 5 \\
\hline & & & & & Artes & 94 & 3 \\
\hline Série/Ano & $\begin{array}{l}\text { Matrículas } \\
\text { iniciais }\end{array}$ & Evasão & Transf. & $\begin{array}{l}\text { Matrículas } \\
\text { finais }\end{array}$ & Disciplinas & Aprov. & Reprov. \\
\hline \multirow{7}{*}{$8^{\circ}$ ano } & \multirow{7}{*}{105} & \multirow{7}{*}{0} & \multirow{7}{*}{1} & \multirow{7}{*}{104} & Português & 104 & 0 \\
\hline & & & & & Matemática & 100 & 4 \\
\hline & & & & & História & 102 & 02 \\
\hline & & & & & Geografia & 93 & 11 \\
\hline & & & & & Ciências & 99 & 5 \\
\hline & & & & & L. Estrangeira & 104 & 0 \\
\hline & & & & & Ed. Física & 97 & 7 \\
\hline
\end{tabular}


Classes Interativas: uma proposta pedagógica

\begin{tabular}{|c|c|c|c|c|c|c|c|}
\hline & & & & & Artes & 97 & 7 \\
\hline Série/Ano & $\begin{array}{l}\text { Matrículas } \\
\text { iniciais }\end{array}$ & Evasão & Transf. & $\begin{array}{l}\text { Matrículas } \\
\text { finais }\end{array}$ & Disciplinas & Aprov. & Reprov. \\
\hline \multirow{8}{*}{$9^{\circ}$ ano } & \multirow{8}{*}{113} & \multirow{8}{*}{1} & \multirow{8}{*}{0} & \multirow{8}{*}{112} & Português & 109 & 3 \\
\hline & & & & & Matemática & 104 & 8 \\
\hline & & & & & História & 108 & 4 \\
\hline & & & & & Geografia & 108 & 4 \\
\hline & & & & & Ciências & 92 & 20 \\
\hline & & & & & L. Estrangeira & 109 & 3 \\
\hline & & & & & Ed. Física & 98 & 14 \\
\hline & & & & & Artes & 108 & 4 \\
\hline
\end{tabular}

\begin{tabular}{|c|c|c|c|c|c|c|c|}
\hline Série/Ano & $\begin{array}{l}\text { Matrículas } \\
\text { iniciais }\end{array}$ & Evasão & Transf. & $\begin{array}{l}\text { Matrículas } \\
\text { finais }\end{array}$ & Disciplinas & Aprov. & Reprov. \\
\hline \multirow{16}{*}{$1^{\circ}$ ano C.N. } & \multirow{16}{*}{327} & \multirow{16}{*}{1} & \multirow{16}{*}{0} & \multirow{16}{*}{326} & Artes & 319 & 7 \\
\hline & & & & & Biologia & 309 & 17 \\
\hline & & & & & Brinquedoteca & 326 & 0 \\
\hline & & & & & Conhe. Didátic & 318 & 8 \\
\hline & & & & & Ed. Física & 326 & 0 \\
\hline & & & & & Filosofia & 320 & 6 \\
\hline & & & & & Física & 291 & 35 \\
\hline & & & & & Geografia & 295 & 31 \\
\hline & & & & & História & 298 & 28 \\
\hline & & & & & Integ Midias & 326 & 0 \\
\hline & & & & & Inglês & 314 & 12 \\
\hline & & & & & Português & 286 & 40 \\
\hline & & & & & Matemática & 289 & 33 \\
\hline & & & & & Prat Ped PPIP & 324 & 2 \\
\hline & & & & & Química & 313 & 13 \\
\hline & & & & & Sociologia & 320 & 6 \\
\hline \multirow{2}{*}{$2^{\circ}$ ano C.N. } & \multirow{2}{*}{195} & \multirow{2}{*}{1} & \multirow{2}{*}{0} & \multirow{2}{*}{194} & Arte e Educ & 191 & 3 \\
\hline & & & & & Biologia & 185 & 8 \\
\hline
\end{tabular}




\begin{tabular}{|c|c|c|c|c|c|c|c|}
\hline & & & & & $\begin{array}{l}\text { Conh Did Ed } \\
\text { Esp }\end{array}$ & \begin{tabular}{|l|}
193 \\
\end{tabular} & 1 \\
\hline & & & & & $\begin{array}{l}\text { Conh Did Ed } \\
\text { Inf }\end{array}$ & 187 & 7 \\
\hline & & & & & $\begin{array}{l}\text { Conh Did Ens } \\
\text { Fund }\end{array}$ & \begin{tabular}{|l|}
192 \\
\end{tabular} & 2 \\
\hline & & & & & Ed. Física & 192 & 2 \\
\hline & & & & & Geografia & 191 & 3 \\
\hline & & & & & História & \begin{tabular}{|l|}
194 \\
\end{tabular} & 0 \\
\hline & & & & & $\begin{array}{ll}\text { His e } & \text { Fil } \\
\text { Educação } & \end{array}$ & \begin{tabular}{|l|l|}
194 \\
\end{tabular} & 0 \\
\hline & & & & & Inglês & \begin{tabular}{|l|}
194 \\
\end{tabular} & 0 \\
\hline & & & & & Português & \begin{tabular}{|l|}
191 \\
\end{tabular} & 3 \\
\hline & & & & & \begin{tabular}{|l|} 
Matemática \\
\end{tabular} & 165 & 2 \\
\hline & & & & & $\begin{array}{ll}\text { Prat } & \text { Pedag } \\
\text { PPIP } & \\
\end{array}$ & 185 & 9 \\
\hline & & & & & \begin{tabular}{|l} 
Prat \\
Psicomotoras
\end{tabular} & 185 & 9 \\
\hline & & & & & $\begin{array}{l}\text { Proc Alfa e } \\
\text { Letramento }\end{array}$ & 190 & 4 \\
\hline & & & & & Psic da Educ & 194 & 0 \\
\hline & & & & & Química & 161 & 3 \\
\hline & & & & & Sociologia & \begin{tabular}{|l|l|}
184 \\
\end{tabular} & 11 \\
\hline & & & & & Arte & 176 & 0 \\
\hline & & & & & $\begin{array}{l}\text { Atend } \\
\text { Educacional }\end{array}$ & $\mid 176$ & 0 \\
\hline & & & & & Conh Did EJA & 176 & 0 \\
\hline & & & & & Conh DIDEI & 176 & 0 \\
\hline & & & & & Conh DIDEF & 176 & 0 \\
\hline $3^{\circ}$ ano C.N. & 178 & 2 & 0 & 176 & Lab Culturas & 176 & 0 \\
\hline & & & & & Ed. Física & $\mid 176$ & 0 \\
\hline & & & & & Física & 175 & 1 \\
\hline & & & & & His e Fil Educ & 176 & 0 \\
\hline & & & & & Inglês & 175 & 1 \\
\hline & & & & & Português & 175 & 1 \\
\hline & & & & & Ling & 176 & 0 \\
\hline
\end{tabular}


Classes Interativas: uma proposta pedagógica

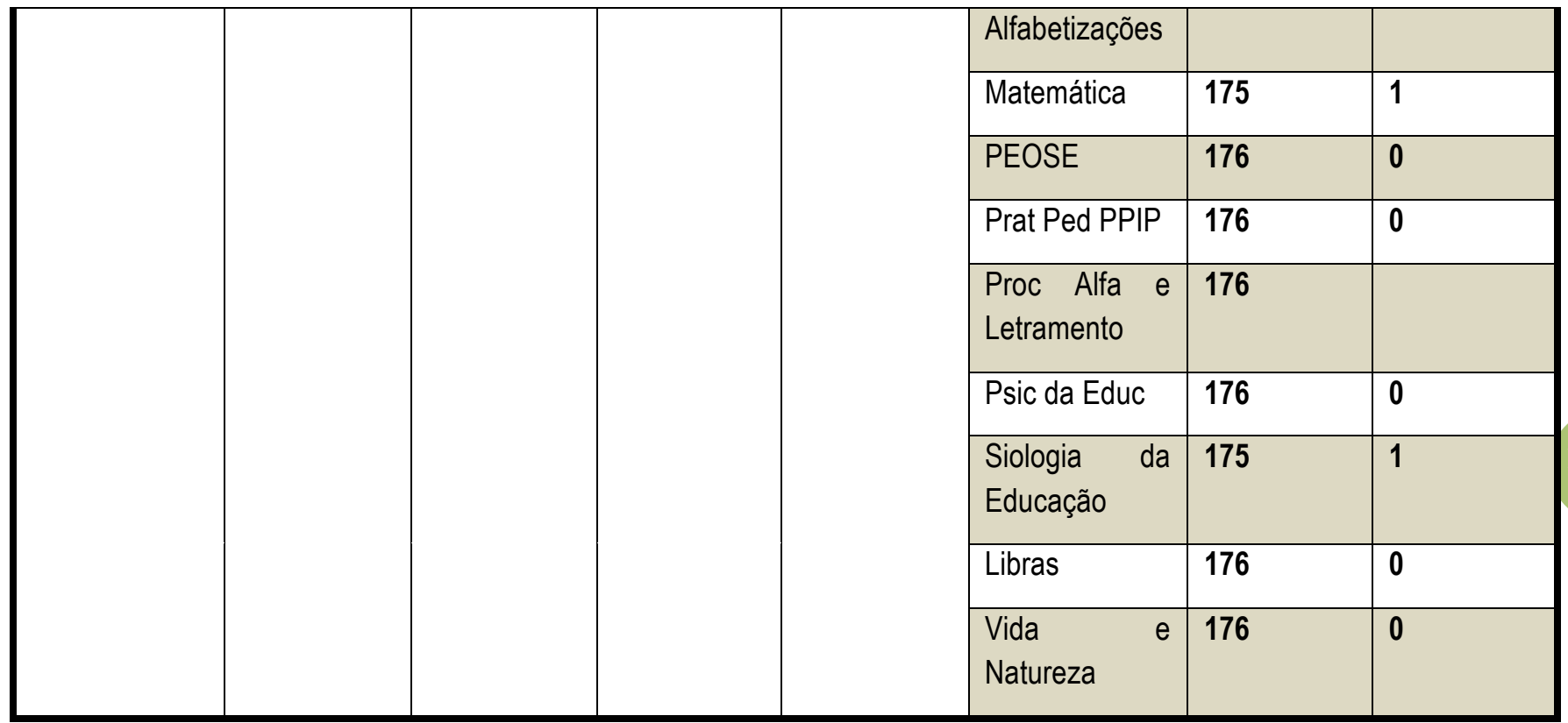

\begin{tabular}{|c|c|c|c|c|c|c|c|}
\hline Série/Ano & $\begin{array}{l}\text { Matrículas } \\
\text { iniciais }\end{array}$ & Evasão & Transf. & $\begin{array}{l}\text { Matrículas } \\
\text { finais }\end{array}$ & Disciplinas & Aprov. & Reprov. \\
\hline \multirow{11}{*}{$1^{\circ}$ ano E.M. } & \multirow{11}{*}{90} & \multirow{11}{*}{12} & \multirow{11}{*}{0} & \multirow{11}{*}{78} & Português & 44 & 34 \\
\hline & & & & & Matemática & 56 & 22 \\
\hline & & & & & História & 61 & 17 \\
\hline & & & & & Geografia & 66 & 12 \\
\hline & & & & & Biologia & 57 & 21 \\
\hline & & & & & L. Estrangeira & 78 & 0 \\
\hline & & & & & Ed. Física & 63 & 15 \\
\hline & & & & & Química & 54 & 24 \\
\hline & & & & & Física & 63 & 15 \\
\hline & & & & & Filosofia & 62 & 16 \\
\hline & & & & & Sociologia & 66 & 12 \\
\hline Série/Ano & $\begin{array}{l}\text { Matrículas } \\
\text { iniciais }\end{array}$ & Evasão & Transf. & $\begin{array}{l}\text { Matrículas } \\
\text { finais }\end{array}$ & Disciplinas & Aprov. & Reprov. \\
\hline \multirow{6}{*}{$2^{\circ}$ ano E.M. } & \multirow{6}{*}{65} & \multirow{6}{*}{8} & \multirow{6}{*}{0} & \multirow{6}{*}{57} & Português & 44 & 13 \\
\hline & & & & & Matemática & 41 & 16 \\
\hline & & & & & História & 48 & 9 \\
\hline & & & & & Geografia & 47 & 10 \\
\hline & & & & & Biologia & 52 & 5 \\
\hline & & & & & L. Estrangeira & 50 & 7 \\
\hline
\end{tabular}




\begin{tabular}{|c|c|c|c|c|c|c|c|}
\hline & & & & & Ed. Física & 50 & 7 \\
\hline & & & & & Artes & 45 & 12 \\
\hline & & & & & Química & 42 & 15 \\
\hline & & & & & Física & 51 & 6 \\
\hline & & & & & Filosofia & 52 & 5 \\
\hline & & & & & Sociologia & 52 & 5 \\
\hline Série/Ano & $\begin{array}{l}\text { Matrículas } \\
\text { iniciais }\end{array}$ & Evasão & Transf. & $\begin{array}{l}\text { Matrículas } \\
\text { finais }\end{array}$ & Disciplinas & Aprov. & Reprov. \\
\hline \multirow{11}{*}{$3^{\circ}$ ano E.M. } & \multirow{11}{*}{109} & \multirow{11}{*}{5} & \multirow{11}{*}{0} & \multirow{11}{*}{104} & Português & 84 & 20 \\
\hline & & & & & Matemática & 80 & 24 \\
\hline & & & & & História & 96 & 8 \\
\hline & & & & & Geografia & 96 & 8 \\
\hline & & & & & Biologia & 103 & 1 \\
\hline & & & & & L. Estrangeira & 101 & 3 \\
\hline & & & & & Ed. Física & 97 & 7 \\
\hline & & & & & Química & 99 & 5 \\
\hline & & & & & Física & 102 & 2 \\
\hline & & & & & Filosofia & 101 & 3 \\
\hline & & & & & Sociologia & 99 & 5 \\
\hline
\end{tabular}

Ao observar os quadros acima se pode concluir que os índices de evasão e transferência em nossa U.E., são mínimos. A maior divergência encontra-se no Ensino Médio noturno, onde a evasão ainda é um problema latente.

Quanto as disciplinas críticas, no Ensino Fundamental, destacam-se MATEMÁTICA, GEOGRAFIA E CIÊNCIAS. Já no Curso Normal o destaque negativo concentra-se em PORTUGUÊS, MATEMÀTICA, QUİMICA e FİSICA. Fator dominante também no Ensino Médio Regular: MATEMÁTICA, QUÍMICA e PORTUGUÊS.

Os maiores índices de reprovação ocorrem no início e término do Ensino Fundamental ( $2^{\mathrm{ao}}$ segmento), no $1^{\circ}$ ano do Curso Normal e também do Ensino Médio.

Tal fato deriva-se, essencialmente, da mudança de estrutura entre um segmento e outro; novas disciplinas, novas metas, objetivos e a falta de acompanhamento familiar nos estudos. Há, ainda, com a aprovação em progressão parcial, uma redução nestes números, porém aumenta-se a responsabilidade de reduzir os índices negativos e completar os módulos de dependência o quanto antes. 


\section{Classes Interativas: uma proposta pedagógica}

\section{Principais problemas identificados}

\begin{tabular}{|l|l|l|l|l|l|}
\hline Problemas & G & U & T & GxUxT & Prioridade \\
\hline Evasão no Ensino Médio - Noturno & 2 & 2 & 2 & 8 & $4^{0}$ \\
\hline Baixo rendimento em disciplinas críticas & 5 & 5 & 5 & 125 & $1^{0}$ \\
\hline $\begin{array}{l}\text { Baixo desempenho no SAERJ do Ensino Médio } \\
\text { - Noturno }\end{array}$ & 4 & 4 & 4 & 64 & $2^{0}$ \\
\hline Falta de acompanhamento familiar & 1 & 1 & 1 & 1 & $5^{0}$ \\
\hline $\begin{array}{l}\text { Alto índice de Progressão Parcial no Ensino } \\
\text { Fundamental }\end{array}$ & 3 & 3 & 3 & 27 & $3^{0}$ \\
\hline
\end{tabular}

\section{Detalhamento do problema}

Utilizou-se o Diagrama de Causa e Efeito para detalhar o problema:
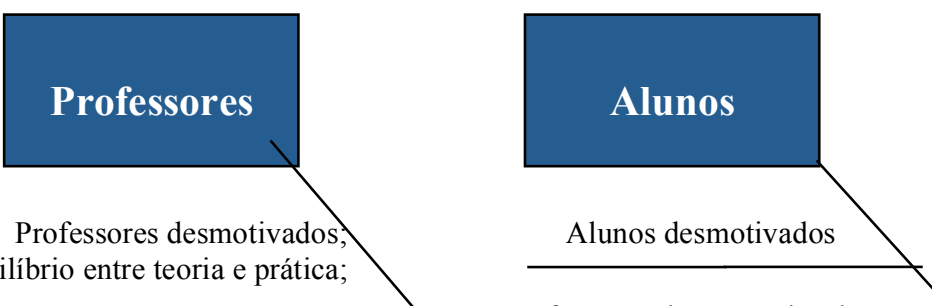

Defasagem de conteúdos de anos

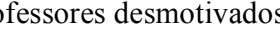

Desequilíbrio entre teoria e prática;

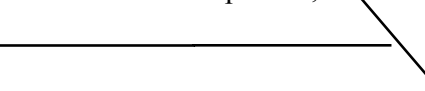

Dificuldade de realizar atividades diversificadas e dinâmicas Necessidade da ajuda financeira dos filhos

Desinteresse dos pais; Dificuldade de controle/limites

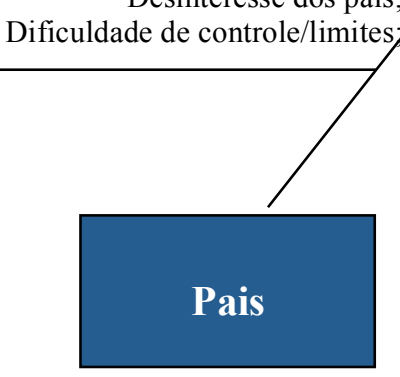
capacitação para professores

\section{Baixo} rendimento dos alunos 


\section{Análise SWOT}

A partir das pesquisas realizadas pela equipe escolar e das discussões sobre o contexto da escola, foi desenvolvida a seguinte Matriz SWOT:

\begin{tabular}{|c|c|c|c|}
\hline & & Aspectos favoráveis & Aspectos desfavoráveis \\
\hline & & FORÇAS & FRAQUEZAS \\
\hline 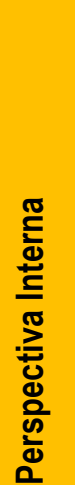 & 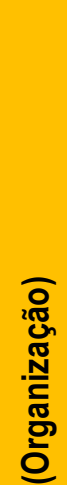 & $\begin{array}{l}\text { Localização da escola } \\
\text { Escola de referência no município. } \\
\text { Corpo docente e funcionários comprometidos } \\
\text { Organização da escola } \\
\text { Proposta pedagógica } \\
\text { Disponibilidade de espaços diversificados e } \\
\text { recursos diferenciados. }\end{array}$ & $\begin{array}{l}\text { Falta de identificação dos alunos com o Curso } \\
\text { Normal } \\
\text { Evasão no Ensino Médio noturno } \\
\text { Defasagem de conteúdos de anos anteriores } \\
\text { Baixo desempenho no SAERJ } \\
\text { Progressão parcial }\end{array}$ \\
\hline & & OPORTUNIDADES & AMEAÇAS \\
\hline 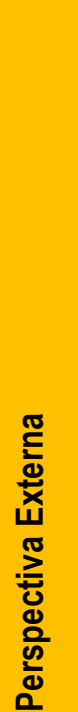 & 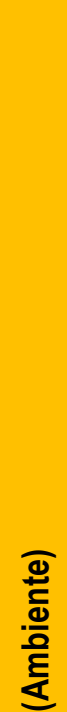 & $\begin{array}{l}\text { Estágios supervisionados nas redes públicas e } \\
\text { privadas } \\
\text { Parcerias com Universidades Público/Privadas, } \\
\text { incluindo projetos de Pesquisa e iniciação } \\
\text { científica } \\
\text { Envolvimento com a comunidade do entorno } \\
\text { criando oportunidades para a comunidade } \\
\text { interna (descontos em cursos diversos, } \\
\text { doações para campanhas) } \\
\text { Passeios culturais / pedagógicos oferecidos } \\
\text { pela SEEDUC e entidades particulares. }\end{array}$ & $\begin{array}{l}\text { Alunos oriundos de comunidades diversas } \\
\text { (incluindo outros municípios) } \\
\text { Ausência de seleção para o Curso Normal } \\
\text { Atrasos constantes nos primeiros tempos de } \\
\text { aula } \\
\text { Crescimento no desinteresse do responsável } \\
\text { na vida escolar do aluno }\end{array}$ \\
\hline
\end{tabular}

Ao analisar o quadro da Matriz SWOT, fica evidente que a escola tem mais Forças do que Fraquezas e mais Oportunidades do que Ameaças. Tal realidade percebida no cotidiano escolar, proporciona de forma ampla e facilitadora a implementação do Plano de Empreendimento, com o objetivo de elevar o desempenho do alunado, assim como manter a qualidade do Ensino.

O projeto aqui apresentado vem de forma significativa atacar à defasagem de conteúdos de anos anteriores, nas disciplinas críticas, associando a teoria à prática, facilitando assim a compreensão dos conteúdos abordados com vivências que possam ser adquiridas e eficazmente apreendidas. 


\section{Ações corretivas}

Visando preparar a organização para o desenvolvimento do projeto, no intuito combater as fraquezas e reduzir os possiveis impactos das ameaças, foram definidas as seguintes ações:

- Desenvolver atividades extracurriculares que reforcem a relação do aluno com a escola.

- Motivar os professores para ministrarem aulas atrativas, unindo teoria à prática utilizando recursos diversificados (vídeos, data show, lousa digital, oficinas, palestras, espaços alternativos...)

- Estimular o interesse dos estudantes para as avaliações externas através de monitoria, simulado, oficinas, laboratórios pedagógicos...

- Realizar encontros periódicos com os responsáveis, destacando a importância da participação destes na vida escolar do aluno elucidando a questão da assiduidade e pontualidade nas aulas.

\section{Oportunidade identificada}

A presente proposta é de desenvolver um projeto que vise diminuir os índices de reprovação e evasão escolar com a implementação da Lousa Digital em todas as salas de aulas, oferecendo e incentivando ao docente o uso da tecnologia e novas mídias na aplicação de seus conteúdos, visando à interdisciplinaridade, tornando acessíveis os equipamentos.

Objetiva tornar as aulas mais atrativas, principalmente nas disciplinas críticas em questão, no Ensino Fundamental: MATEMÁTICA, GEOGRAFIA e CIÊNCIAS. Curso Normal: LÍNGUA PORTUGUESA, MATEMÁTICA, QUÍMICA e FÍSICA. Ensino Médio Regular: MATEMÁTICA, QUÍMICA e LÍNGUA PORTUGUESA. Auxiliando na compreensão dos conteúdos, despertando maior interesse do aluno e atração nas novas mídias e tecnologias, oferecendo atividades diversificadas e práticas, visando um melhor desempenho.

Acredito com isso que o uso deste recurso pedagógico (lousa digital), possa efetivamente diminuir o número de reprovação, assim como o alto índice de evasão, principalmente do ensino médio, que se sentem mais desmotivados.

\section{Detalhamento do produto/serviço e/ou processo}

Contemplando o próprio Currículo Mínimo desta Secretaria de Educação (SEEDUC), que trata na parte diversificada, a necessidade no mundo globalizado, oferecer condições e acesso a novas mídias e tecnologias da informação e comunicação $(\mathrm{TIC})$, aproximando o conhecimento da teoria à prática. Desenvolvendo esta proposta a partir do Curso Normal (Formação de Professores), que proporcionará no momento do exercício de sua profissão, mais uma ferramenta para facilitar o processo ensino-aprendizagem. Devido à globalização existe a necessidade da apropriação dos recursos tecnológicos. A proposta é de implantação a partir da $1^{\text {a }}$ série do Curso Normal, nas demais séries e ainda ao Ensino Médio Regular e Ensino Fundamental, auxiliando nas disciplinas críticas com intuito de tornar as aulas mais atrativas e consequentemente facilitar 0 aprendizado deste aluno.

A proposta do $1^{\circ}$ ano do Curso Normal prevê em suas habilidades e competências que se trabalhe a temática "a integração das mídias e tecnologias" ressaltamos os seguintes objetivos:

- Refletir sobre a influência do uso das tecnologias disponíveis na sociedade, na vida e na escola;

- Explorar os recursos multimidiáticos e a internet na prática docente;

- Conhecer as diferentes linguagens midiáticas que favorecem a prática educativa;

- Apresentar possibilidades de exploração das diversas ferramentas tecnológicas como suporte a atividades pedagógicas;

- Identificar a usabilidade dos jogos e programas educativos que facilitam a aprendizagem escolar; 


\section{Foco do projeto}

O objetivo do Projeto de Implementação de Lousas Digitais nas salas do Ensino Fundamental, Médio e Curso Normal, é buscar maior interação do aluno com o conteúdo didático através da tecnologia oferecida pela Lousa Digital, ampliando sua capacidade de aprendizado e as possibilidades do professor.

De acordo com pesquisas de mercado, a Lousa Digital é efetivamente uma ferramenta didática utilizada pelas melhores instituições de ensino em nível global, com resultados positivos comprovados por alunos com maiores índices de aprendizado, por instituições renomadas com projetos em andamento ou finalizadas de implantação desse equipamento e por instituições em crescimento movido pelo uso de Lousas Digitais em salas de aula.

Série ou conjunto de séries beneficiadas: $1^{\text {a }}$ série do Curso Normal e $1^{\circ}$ ano do Ensino Médio Regular. Ampliaremos as demais séries gradativamente.

Disciplina ou conjunto de disciplinas trabalhadas: 0 projeto tem o intuito atender a todas as disciplinas, principalmente as críticas, para atrair a atenção dos alunos e possibilitar uma maior interação no processo ensinoaprendizagem, que são elas:. Ensino Fundamental - MATEMÁTICA, GEOGRAFIA e CIÊNCIAS. Curso Normal LÍNGUA PORTUGUESA, MATEMÁTICA, QUÍMICA e FÍSICA. Ensino Médio Regular - MATEMÁTICA, QUÍMICA e LIINGUA PORTUGUESA.

\section{Etapas do projeto}

O projeto será composto pelas seguintes etapas:

- Aquisição de Lousas Digitais/Material didático (tratativa com os fornecedores e agendamento/recebimento da entrega dos pedidos);

- Instalação (preparação da infra-estrutura e instalação dos aparelhos);

- Elaboração do treinamento (elaboração do material/plano de aulas do treinamento para familiarização dos professores com a ferramenta implementada e o novo material didático);

- Treinamento (agendamento/realização do treinamento com os professores).

\section{Etapa 1 - AQUISIÇÃO DE EQUIPAMENTOS, ADAPTAÇÃO E ADEQUAÇÃO DO ESPAÇO FÍSICO}

Objetivo: Identificar o que é necessário com relação ao espaço físico idealizado e o material necessário para implantação do projeto.

Impacto na aprendizagem: Essa etapa ainda não prevê resultados de impacto na aprendizagem, uma vez que a mesma está em fase de preparação para a implementação do projeto.

Atividades a serem realizadas: Cotação de preços dos equipamentos necessários para utilização das lousas digitais e obras de adaptação e adequação das salas de aula. 
Atividade 1.1

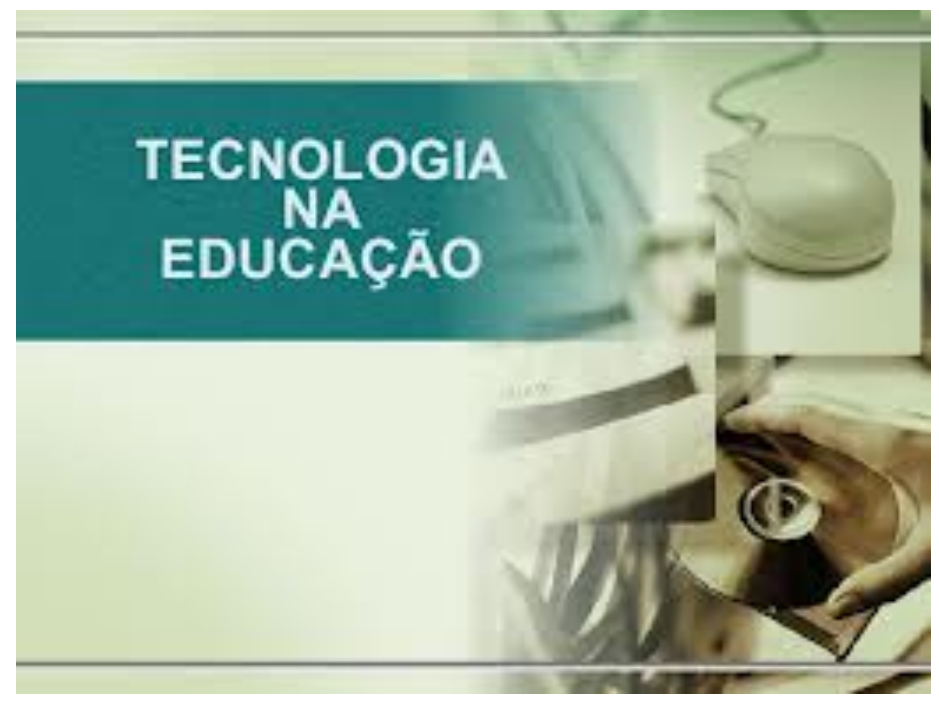

Descrição: Avaliação do espaço físico e levantamento de orçamento para execução das obras e aquisição dos equipamentos. (mínimo 3 orçamentos).

Duração: 2 meses (janeiro a fevereiro 2015).

Recursos necessários: (Lousa digital, projetores, suporte de projetores, adequação das salas de aula e instalação dos equipamentos).

Equipe envolvida: Gestor, equipe pedagógica (coordenador pedagógico, articulador pedagógico, mediadores tecnológicos (Núcleo de Tecnologia de Educação - NTE), docentes e alunos, SITICOMMM (Sindicato dos Trabalhadores na Indústria da Construção Civil, Montagem Industrial, Mobiliário, Mármore e Granito e do Vime de Duque de Caxias,São João de Meriti, Nilópolis, Magé e Guapimirim), profissionais habilitados para execução dos serviços ..

\section{Atividade 1.2}

Descrição: Execução das obras de adequação dos espaços físicos para implantação dos equipamentos.

Duração: 2 meses

Recursos necessários: Lousa digital, projetor, computador, quadro branco, instalação elétrica, suporte de teto para projetor.

Equipe envolvida: Gestor, Equipe técnica pedagógica, mediador tecnológico SITICOMMM (Sindicato dos Trabalhadores na Indústria da Construção Civil, Montagem Industrial, Mobiliário, Mármore e Granito e do Vime de Duque de Caxias,São João de Meriti, Nilópolis, Magé e Guapimirim), profissionais habilitados para execução dos serviços .

Equipe envolvida: Equipe técnica pedagógica, mediador tecnológico e docente das disciplinas criticas do Ensino Médio.

\section{Atividade 1.3}

Descrição: Levantamento das disciplinas críticas do Curso Normal, Ensino Médio e Fundamental.

Duração: 1 mês

Recursos necessários: Computador com internet

Equipe envolvida: Gestor, Equipe Técnico Pedagógica e docentes das disciplinas críticas.

Etapa 2 - CAPACITAÇÃO E TREINAMENTO DA LOUSA DIGITAL NO AMBIENTE ESCOLAR 
Objetivo: Por meio deste recurso, metodologias diferenciadas poderão ser inseridas no ambiente educacional, proporcionando ao docente o uso da tecnologia, auxiliando a fazer de forma mais eficiente o que já desenvolve, utilizando a linguagem que faz parte do universo dos alunos ao ambiente pedagógico.

Impacto na aprendizagem: Possibilitar a apresentação do conteúdo curricular de modo diferenciado, proporcionando 0 processo ensino-aprendizagem mais interessante, tanto para o professor, quanto para 0 aluno.

Atividades a serem realizadas: Levantamento através do mapa de notas do próprio sistema conexão educação. Reuniões com professores por área, para obter informação diagnóstica dos motivos do baixo desempenho.

Palestras sobre mídias e as tecnologias da informação e comunicação na sociedade, na vida e na escola. Apresentação de desenvolvimento do conteúdo didático com utilização de recursos tecnológicos.

\section{Atividade 2.1}

Descrição: Oficina Básica de lousa digital - Módulo I: Conhecer o software e o hardware. Salvar, exportar, editar e criar documentos no starboard. Apagar, selecionar formas geométricas e preencher. Barra lateral (criar e excluir páginas, etc.) Reconhecimento de texto. Pesquisando e editando textos e imagens na internet. Acessórios (captura de imagem, cronômetro).

\section{Duração: 1 mês}

Recursos necessários: computador com acesso a internet, projetor multimídia, lousa digital, câmera e filmadora digital para registro das atividades, caixa de som, apostila e material de consumo para continuidade do portfólio do projeto.

Equipe envolvida: Gestores, Equipe técnico pedagógica, professores das disciplinas críticas. Professores Mediadores do Núcleo de Tecnologia Educacional (NTE).

\section{Atividade 2.2}

Descrição: Oficina Básica de lousa digital - Módulo Il: Flash, hiperlin clone infinito. Anexos e lista de tópicos. Interação com o Power point, Word, PDF e Excel. Galeria: imagens, Google e favoritos. Acessórios (compasso, transferidos, régua, holofote, gravador de tela).

Duração: 1 mês

Recursos necessários: computador com acesso a internet, projetor multimídia, lousa digital, câmera e filmadora digital para registro das atividades, caixa de som, apostila e material de consumo para continuidade do portfólio do projeto.

Equipe envolvida: Gestores, Equipe técnico pedagógica, professores das disciplinas críticas, Professores Mediadores do Núcleo de Tecnologia Educacional (NTE).

\section{Atividade 2.3}

Descrição: Oficina Básica de lousa digital - Módulo III: Workshop. Os docentes irão se organizar em duplas por áreas e estruturar uma aula seguindo um tema de sua preferência.

Duração: 1 mês

Recursos necessários: computador com acesso a internet, projetor multimídia, lousa digital, câmera e filmadora digital para registro das atividades, caixa de som, apostila e material de consumo para continuidade do portfólio do projeto.

Equipe envolvida: Gestores, Equipe técnico pedagógica, professores das disciplinas críticas. Professores Mediadores do Núcleo de Tecnologia Educacional (NTE).

\section{Etapa 3 - DESENVOLVENDO INTERAÇÃO ATRAVÉS DA TECNOLOGIA NAS DISCIPLINAS CRÍTICAS}

Objetivo: Desenvolver nova metodologia ensino aprendizado através do uso da tecnologia e novas mídias.

Impacto na aprendizagem: Oferecer condições do aluno compreender e assimilar os conteúdos, a partir da visualização e de atividades interativas, tornando as aulas mais atrativas. 
Atividades a serem realizadas: Seminários, palestras e dinâmicas de grupo utilizando os jogos pedagógicos e a tecnologia.

\section{Atividade 3.1}

Descrição: Aplicar bateria de exercícios dos anos anteriores, para verificar quais os conteúdos que existe defasagem ensino-aprendizagem. Exemplo alunos do $1^{\circ}$ ano terão avaliação das disciplinas críticas, no $1^{\circ}$ mês referente ao $9^{\circ}$ ano do ensino fundamental.

Duração: 1 mês

Recursos necessários: 4 resmas de papel A 4 e Xerox.

Equipe envolvida: Gestor, Equipe técnico pedagógica, docentes das disciplinas críticas e alunos do $1^{\circ}$ ano do Curso Normal e Ensino Médio.

\section{Atividade 3.2}

Descrição: Reunião com os responsáveis, envolvendo os mesmos no acompanhamento e das ações que estão sendo tomadas pela unidade escolar, para diminuir a evasão escolar e melhorar desempenho do aluno.

Duração: 9 etapas divididos trimestral.

Recursos necessários: Computador, projetor, lousa digital, e material de divulgação (bilhetes de convocação).

Equipe envolvida: Gestor, Equipe técnico pedagógica, docentes das disciplinas críticas, alunos e responsáveis do $1^{\circ}$ ano do Curso Normal e Ensino Médio.

\section{Atividade 3.3}

Descrição: Estimular através de seminários a assimilação dos conteúdos didáticos das disciplinas críticas

Duração: 3 meses que ocorrerá sempre no último bimestre.

Recursos necessários: Computador com internet, projetor e lousa digital.

Equipe envolvida: Gestor, Equipe Técnico-pedagógica, docentes das disciplinas críticas e alunos.

\section{Etapa 4 - ACOMPANHAMENTO E CORREÇÕES DAS AÇÕES}

Objetivo: Diagnosticar as falhas ocorridas durante o processo e efetuar as devidas correções.

Impacto na aprendizagem: Proporcionar aos alunos uma melhor ação durante o projeto, para uma melhor aplicação das atividades propostas.

Atividades a serem realizadas:

\section{Atividade 4.1}

Descrição: Analise através das avaliações externas e internas do desempenho dos alunos.

Duração: Semestralmente

Recursos necessários: Computador com internet, impressora, acesso ao sistema conexão educação e resma de papel A4.

Equipe envolvida: Gestor, Equipe Técnico pedagógica, docentes e alunos.

\section{Atividade 4.2}

Descrição: Aplicar questionário diagnóstico entre discentes, docentes e responsáveis.

Duração: ao final de cada ano (anual) 
Recursos necessários: Computador, impressora e resma de papel A4

Equipe envolvida: Gestor, Equipe Técnico-pedagógica, docentes, alunos e responsáveis.

\section{Casos de sucesso}

Nome do Projeto: Classes Interativas

Nome da organização: Rede Municipal de Guarujá

Local: Cidade do Guarujá / S.P.

Período em que foi realizado: 2013

Breve relato do contexto anterior ao projeto:

O estudo envolveu 240 alunos da Escola Municipal Francisco Figueiredo; a amostra inclui desde a sexta até a nona série. "A classe 6A, por exemplo, foi uma das que mostrou resultados mais impactantes: antes das aulas passarem a acontecer no ambiente multimídia, apenas $35 \%$ da turma atingia conceitos satisfatórios; com a entrada em cena das novas tecnologias e a possibilidade de dar aulas muito mais interativas, $80 \%$ da turma passou a apresentar conceitos satisfatórios", diz Bellomusto.

Principais atividades desenvolvidas:

Resumo dos principais resultados alcançados:

Fonte: www.sapienti.inf.br/novo/prefeitura-do-guaruja-usa-salas-multimidias-sapienti.php

\section{Novidade trazida pelo projeto}

Uma vez concluído o projeto com sucesso, espera-se que as Lousas Digitais conquistem um maior interesse do aluno, ampliando sua capacidade de aprendizado.

Este projeto tem a ambição de criar um diferencial para nossa Unidade Escolar como instituição de ensino, tornando-a pioneira na região no uso de Lousas Digitais como ferramenta didática, mas não somente em uma sala, mas em todas as salas, sem a necessidade de montagem e deslocamento de equipamentos dificultando a utilização dos mesmos, pelos docentes.

Com a utilização da lousa digital como ferramenta neste processo de ensino-aprendizagem, todos os recursos multimídia de um computador se tornarão ainda mais interativos. 
Classes Interativas: uma proposta pedagógica

Cronograma de execução

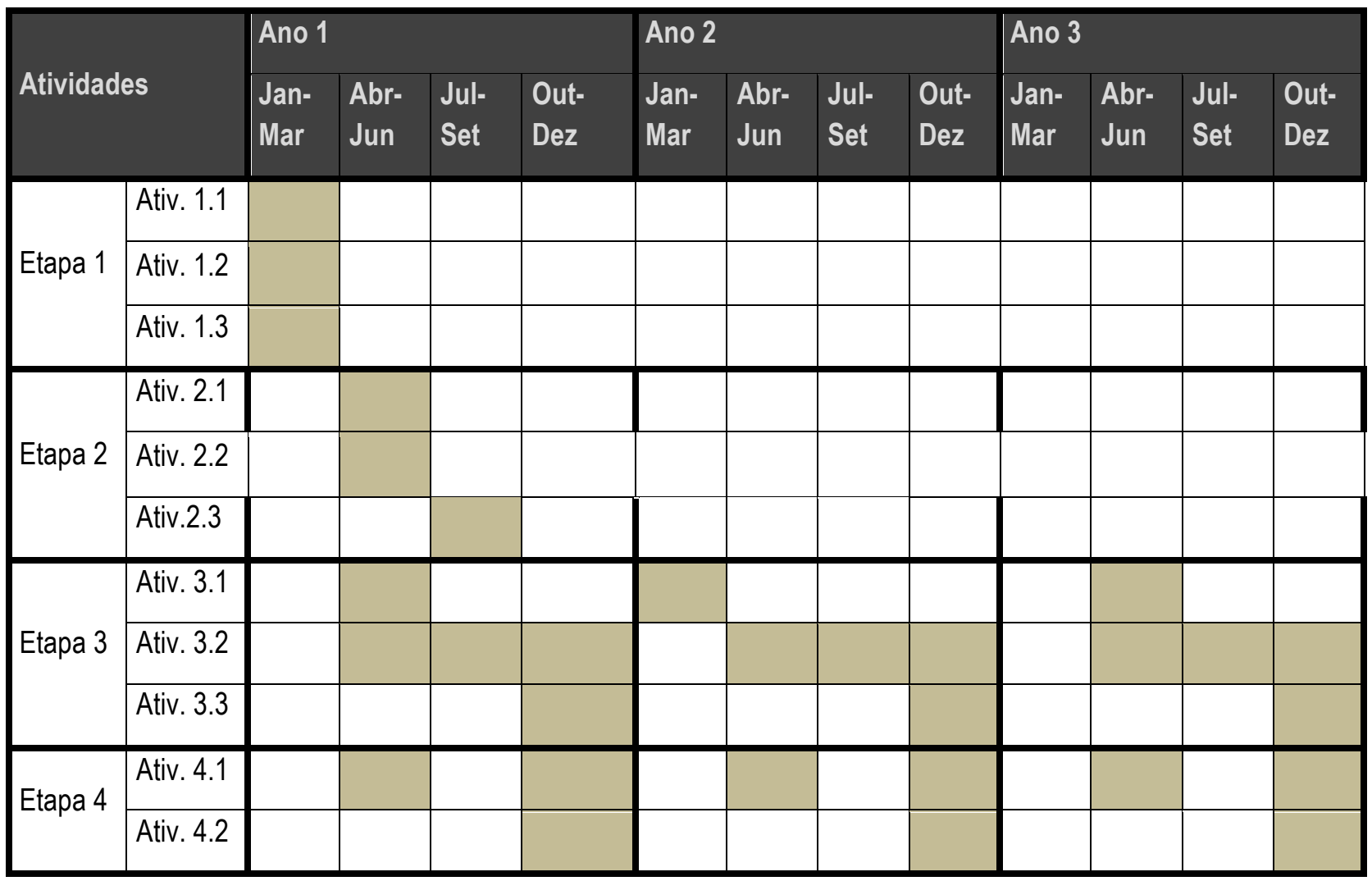




\section{Gestão estratégica}

\section{Objetivos estratégicos}

\begin{tabular}{|c|c|c|c|}
\hline Objetivos & Metas & Indicadores & Acompanhamento \\
\hline \multirow{2}{*}{$\begin{array}{l}\text { Elevar o índice } \\
\text { do IDERJ no } \\
\text { Curso Normal e } \\
\text { Médio }\end{array}$} & $\begin{array}{l}\text { Obter } 4,6 \text { de IDERJ ao final de } \\
2017 .\end{array}$ & $\begin{array}{l}\text { Avaliações internas } \\
\text { e externas } \\
\text { (SAERJINHO) e } \\
\text { relatórios r de } \\
\text { turmas. }\end{array}$ & $\begin{array}{l}\text { Controle bimestral do rendimento } \\
\text { das turmas e definição de ações } \\
\text { corretivas (RADMI), relatório de } \\
\text { alunos e professores. }\end{array}$ \\
\hline & $\begin{array}{l}\text { Alcançar a meta estabelecida } \\
\text { na avaliação externa X para } \\
\text { disciplinas críticas até o final } \\
\text { do projeto. }\end{array}$ & $\begin{array}{l}\text { Resultado da } \\
\text { avaliação externa X } \\
\text { para o ano de } 2015 \\
\text { a } 2017 .\end{array}$ & $\begin{array}{l}\text { Análise bimestral de habilidades } \\
\text { necessárias. Discussão e } \\
\text { estabelecimento de ações } \\
\text { específicas com base nas } \\
\text { avaliações anuais e nos } \\
\text { simulados. }\end{array}$ \\
\hline $\begin{array}{l}\text { Reduzir a taxa } \\
\text { de alunos } \\
\text { aprovados com } \\
\text { progressão } \\
\text { parcial }\end{array}$ & $\begin{array}{l}\text { Diminuir em } 50 \% \text { ao longo da } \\
\text { realização do projeto durante } \\
3 \text { anos }\end{array}$ & $\begin{array}{l}\text { Ficha de } \\
\text { acompanhamento } \\
\text { bimestral }\end{array}$ & $\begin{array}{l}\text { Reuniões bimestrais com os } \\
\text { responsáveis dos alunos com } \\
\text { maior índice de faltas }\end{array}$ \\
\hline 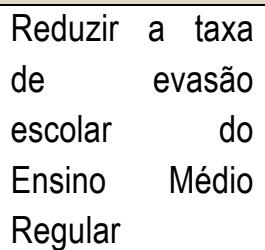 & $\begin{array}{l}\text { Diminuir em } 30 \% \text { a evasão } \\
\text { escolar durante a realização } \\
\text { do projeto }\end{array}$ & $\begin{array}{l}\text { Ficha de } \\
\text { acompanhamento } \\
\text { bimestral }\end{array}$ & $\begin{array}{l}\text { Contato telefônico e visitação na } \\
\text { residência dos alunos evadidos }\end{array}$ \\
\hline
\end{tabular}

\section{Continuidade do projeto}

Todos os recursos multimídia de um computador se tornam ainda mais interativos. Usando os dedos ou uma caneta especial, o professor pode arrastar figuras, copiar, colar, acessar a internet, criar exercícios, abrir arquivos, vídeos e apresentações, interagir com a classe e, o mais interessante, salvar tudo e, depois, disponibilizar na internet para a consulta dos alunos.

Os recursos da tecnologia irão proporcionar aos docentes e discentes um novo olhar neste processo ensino aprendizagem. São muitas opções novas, que o quadro-negro e o giz jamais poderiam oferecer. Portanto, além de entender 0 uso do equipamento, a criatividade de quem comanda as aulas será testada todos os dias. Não bastará encher de palavras, como antigamente. Agora, o material pode e deverá ser mais rico e vivo. 


\section{Marketing e comunicação}

\section{Lançamento do projeto}

Enviaremos email institucional e pessoal a todos os docentes. Divulgação no blog da Unidade Escolar, para tornar público as novas ações que serão tomadas para aumentar o desempenho dos alunos. Na reunião de volta as aulas e planejamento, iremos apresentar a presente proposta e oferecer a oficina básica de utilização da lousa digital para todos os docentes e principalmente das disciplinas críticas, que ocorrerá no Núcleo Tecnológico (NTE).

No período de matrícula e renovação, todos os responsáveis tomarão ciência da necessidade de comparecimento na aula inaugural, com intuito de maior envolvimento dos responsáveis. A aula inaugural acontecerá no primeiro dia letivo com alunos e responsáveis no auditório da escola.

\section{Canais de comunicação e acompanhamento do projeto}

\section{Marketing interno}

Utilizaremos mural na sala dos professores, informando a importância da participação e envolvimento para o sucesso do projeto, com lembrete da data de reunião e das disciplinas necessárias a participar.

Utilizaremos também as redes sociais estimulando o uso da tecnologia.

Envio de e-mails institucionais e pessoais, reforçando o projeto.

\section{Marketing externo}

Banner informativo dos projetos que serão desenvolvidos no próximo ano, fixado na entrada da escola.

Carta convite do comparecimento dos responsáveis nas datas previamente definidas em calendário que será afixado na portaria da Unidade Escolar, secretaria escolar e mural externo. Blog da Unidade Escolar, atualizando as informações quinzenalmente.

\section{Parceiros estratégicos}

Hitachi - Indústria: fabricante

Teremos um parceiro que será fundamental na implementação do nosso projeto. 0 papel da Hitachi é de doação dos equipamentos (21 lousas digitais) no valor unitário de $R \$ 3650,00$, perfazendo um total de $R \$ 76.650,00$ numa proposta pioneira de implantação dos mesmos nas salas de aula. Ainda proporcionar oficinas de utilização do equipamento $\mathrm{e}$ acompanhamento das ações, através de registros e relatórios que serão produzidos e encaminhados a equipe pedagógica da empresa.

A contrapartida da Unidade Escolar é oferecer as instalações adequadas para recebimento das lousas digitais e docentes que irão participar das capacitações e treinamento na utilização da lousa e explorar os recursos que a mesma oferece para desenvolvimento dos seus conteúdos.

Será enviada a cópia do projeto, solicitando esta parceria que será pioneira nas escolas públicas com Curso de Formação de Professores, pois propiciará aos alunos esta experiência ímpar que ampliará seus conhecimentos e futuramente desenvolver suas propostas profissionais utilizando o mesmo equipamento e outras mídias.

Divulgação de resultados ao final de cada ano, através do relatório impresso do sistema conexão educação com o desempenho dos alunos nas disciplinas críticas que terão acompanhamento durante o ano letivo a cada bimestre.

Ao final de cada ano iremos propor uma Mesa Redonda com os profissionais envolvidos no projeto, bem como equipe pedagógica da Empresa Hitachi (parceira no projeto), para apresentar os resultados obtidos e proporcionar debate para os avanços no projeto (quais as dificuldades encontradas e ações bem sucedidas). 


\section{Equipe do projeto}

\section{Equipe interna}

\begin{tabular}{|c|c|c|c|c|}
\hline Cargo & Formação & $\begin{array}{l}\text { Tempo na } \\
\text { escola }\end{array}$ & Experiência anterior & $\begin{array}{l}\text { Responsável pelas } \\
\text { atividades: }\end{array}$ \\
\hline Diretora Geral & $\begin{array}{l}\text { Especialização em } \\
\text { Gestão Escolar }\end{array}$ & 18 anos & $\begin{array}{l}\text { Professor de Educação } \\
\text { Física; Diretora Adjunta }\end{array}$ & $\begin{array}{l}\text { Pesquisa e } \\
\text { elaboração do projeto; } \\
\text { Responsável } \\
\text { Orçamentária. }\end{array}$ \\
\hline Diretor Adjunto & $\begin{array}{ll}\text { Especialização } & \text { em } \\
\text { Gestão Escolar } & \end{array}$ & 18 anos & $\begin{array}{l}\text { Professor de Educação } \\
\text { Física }\end{array}$ & $\begin{array}{l}\text { Elaboração do projeto } \\
\text { e acompanhamento. }\end{array}$ \\
\hline $\begin{array}{l}\text { Diretora Adjunta } \\
\text { Manutenção }\end{array}$ & $\begin{array}{l}\text { Especialização em } \\
\text { Gestão Escolar }\end{array}$ & 17 anos & $\begin{array}{lrr}\text { Professora } & \text { de } & \text { Língua } \\
\text { Portuguesa; } & \text { Diretora } \\
\text { Adjunta } & & \end{array}$ & Elaboração do projeto \\
\hline $\begin{array}{l}\text { Mediador } \\
\text { Tecnológico }\end{array}$ & $\begin{array}{l}\text { Técnico em Mídias } \\
\text { Educacionais }\end{array}$ & 12 anos & $\begin{array}{l}\text { Professor de Educação } \\
\text { Física }\end{array}$ & $\begin{array}{lr}\text { Instalação } & \text { dos } \\
\text { equipamentos } & \mathrm{e} \\
\text { Capacitação } & \text { dos } \\
\text { docentes } & \end{array}$ \\
\hline $\begin{array}{l}\text { Coordenador } \\
\text { Pedagógico }\end{array}$ & Pedagoga & 29 anos & $\begin{array}{ll}\text { Regente } & \text { Disciplinas } \\
\text { Pedagógicas } & \end{array}$ & $\begin{array}{lr}\text { Pesquisa } & \text { e } \\
\text { elaboração; } \\
\text { Responsável pelas } \\
\text { ações com os } \\
\text { docentes e alunos }\end{array}$ \\
\hline $\begin{array}{l}\text { Orientadora } \\
\text { Educacional }\end{array}$ & Pedagoga & 20 anos & $\begin{array}{ll}\text { Regente } & \text { Disciplinas } \\
\text { Pedagógicas } & \end{array}$ & $\begin{array}{l}\text { Pesquisa } \\
\text { elaboração; } \\
\text { Responsável pelas } \\
\text { ações com os } \\
\text { docentes e alunos. }\end{array}$ \\
\hline Professor Regente & $\begin{array}{l}\text { Curso Superior em } \\
\text { Letras }\end{array}$ & 10 anos & $\begin{array}{l}\text { Professor Regente Língua } \\
\text { Portuguesa }\end{array}$ & $\begin{array}{l}\text { Desenvolver as ações } \\
\text { com os discentes; } \\
\text { Apresentar relatórios } \\
\text { a final de cada } \\
\text { bimestre }\end{array}$ \\
\hline Professor Regente & $\begin{array}{l}\text { Licenciatura Plena } \\
\text { em Matemática }\end{array}$ & 01 ano & $\begin{array}{l}\text { Professor Regente } \\
\text { Matemática }\end{array}$ & $\begin{array}{l}\text { Desenvolver as ações } \\
\text { com os discentes; } \\
\text { Apresentar relatórios } \\
\text { ao final de cada } \\
\text { bimestre }\end{array}$ \\
\hline
\end{tabular}




\section{Classes Interativas: uma proposta pedagógica}

\section{Profissionais externos}

\begin{tabular}{|l|l|l|}
\hline Tipo de profissional & Competências necessárias & Participação no projeto \\
\hline Instrutora de Treinamento & $\begin{array}{l}\text { Conhecimento em Tecnologias } \\
\text { Educacionais }\end{array}$ & $\begin{array}{l}\text { Capacitação do equipamento } \\
\text { (Lousa Digital) }\end{array}$ \\
\hline $\begin{array}{l}\text { Professor de Mídias } \\
\text { Educacionais }\end{array}$ & $\begin{array}{l}\text { Especialização em Mídias } \\
\text { Educacionais }\end{array}$ & Palestras semestrais \\
\hline
\end{tabular}

\section{Plano financeiro}

Investimentos (despesas de capital)

\begin{tabular}{|l|l|l|l|}
\hline Item & Ano1 & Ano2 & Ano3 \\
\hline Obras e infra estrutura & $6.500,00$ & $1.060,00$ & $1.123,60$ \\
\hline Obras e infra estrutura & $2.500,00$ & & \\
\hline Instalações & $3.000,00$ & & \\
\hline Manutenção dos equipamentos & $1.000,00$ & $1.060,00$ & $1.123,60$ \\
\hline Material permanente & & & \\
\hline 21 Computadores & $47.953,27$ & 0,00 & 0,00 \\
\hline 21 Projetores & $12.579,00$ & & \\
\hline 1 Câmera digital & $28.899,99$ & & \\
\hline 21 Caixa de som & 349,00 & & \\
\hline Total & $6.125,28$ & & $1.123,60$ \\
\hline
\end{tabular}

Detalhamento dos equipamentos (Material permanente):

- Computador - N3 com Processador Intel Celeron - J1800 Dual Core, 4GB de memória, 500GB de HD, HDMl e Gravador de DVD. Valor unitário R\$599,00

- Projetor EPSON - Power Lite S17. Valor unitário R\$1.376,19

- Câmera Digital - Sony Cyber Shot DSC W800. Valor unitário R\$ 349,00

- Caixa de Som - JBL C321 30W RMS. Valor unitário R \$291,68 


\section{Despesas correntes}

\begin{tabular}{|l|l|l|l|}
\hline Material de consumo & Ano 1 & Ano 2 & Ano 3 \\
\hline Papelaria & 3600 & 3816 & 4044,96 \\
\hline Tonner & 840 & 890,4 & 943,82 \\
\hline Total & 4440,00 & 4706,40 & 4988,78 \\
\hline
\end{tabular}

\begin{tabular}{|l|l|l|l|}
\hline Serviços de terceiros & Ano 1 & Ano 2 & Ano 3 \\
\hline Capacitação de docentes & 600 & 3900 & 4579,2 \\
\hline Manutenção de equipamento & 1000 & 1060 & 1123,6 \\
\hline Serviços Gráficos & 750 & 795 & 842,7 \\
\hline Palestrante & 1600 & 1696 & 1797,3 \\
\hline Total & $3.950,00$ & $7.451,00$ & 8342,8 \\
\hline
\end{tabular}

\section{Recursos do edital}

\begin{tabular}{|l|l|l|l|l|}
\hline Tipo de item & Ano 1 & Ano 2 & Ano 3 & Total \\
\hline Despesas de Capital & $\mathbf{5 4 . 4 5 3 , 2 7}$ & $1.060,00$ & $1.123,60$ & $\mathbf{5 6 . 6 3 6 , 8 7}$ \\
\hline Obras e infraestrutura & $\mathbf{6 . 5 0 0 , 0 0}$ & $\mathbf{1 . 0 6 0 , 0 0}$ & $1.123,60$ & $8.683,60$ \\
\hline Material permanente & $\mathbf{4 7 . 9 5 3 , 2 7}$ & $\mathbf{0 , 0 0}$ & $\mathbf{0 , 0 0}$ & $47.953,27$ \\
\hline Despesas Correntes & $\mathbf{8 . 3 9 0 , 0 0}$ & $\mathbf{1 2 . 1 5 7 , 4 0}$ & $13.331,58$ & $\mathbf{3 3 . 8 7 8 , 9 8}$ \\
\hline Material de consumo & $4.440,00$ & $4.706,40$ & $4.988,78$ & $14.135,18$ \\
\hline Gastos com locomoção & 0,00 & 0,00 & 0,00 & 0,00 \\
\hline Serviços de terceiros & $3.950,00$ & $7.451,00$ & 8342,8 & $19.743,80$ \\
\hline Total do projeto & $62.843,27$ & $13.217,40$ & $14.455,18$ & $90.515,85$ \\
\hline
\end{tabular}




\section{Classes Interativas: uma proposta pedagógica}

\section{Contrapartida}

\begin{tabular}{|l|l|l|l|}
\hline Profissionais & $\begin{array}{l}\text { Horas dedicadas } \\
\text { ao projeto }\end{array}$ & Valor médio/hora & $\begin{array}{l}\text { Contrapartida por } \\
\text { profissional }\end{array}$ \\
\hline Mediador Tecnológico & 16 horas mensais & 16,10 & 257,60 \\
\hline $\begin{array}{l}\text { Coordenação Pedagógica } \\
\text { Orientador Educacional }\end{array}$ & 16 horas mensais & 16,10 & 257,60 \\
\hline $\begin{array}{l}\text { Professor Regente Língua } \\
\text { Portuguesa }\end{array}$ & 16 horas mensais & 16,10 & 257,60 \\
\hline $\begin{array}{l}\text { Professor Regente Língua } \\
\text { Portuguesa }\end{array}$ & 16 horas mensais & 16,10 & 257,60 \\
\hline Total de contrapartida & 80 & 16,10 & 257,60 \\
\hline
\end{tabular}

$\mathrm{R} \$ 1.288,00$ ao mês $\times 12$ meses $=\mathrm{R} \$ 15.456,00\left(1^{\circ} \mathrm{ano}\right)$

No $2^{\circ}$ ano $R \$ 16383,36$ (reajuste $6 \%$ )

No $3^{\circ}$ ano $R \$ 17366,36$ (reajuste $6 \%$ ) 